\title{
Place of Academic Discourse in Corporate Culture of Modern University
}

\author{
Yulia N. Zemskaya ${ }^{1}$, Anna V. Glagoleva ${ }^{1, *}$, Evgeniya A. Kuznetsova ${ }^{1}$ and Irina Y. \\ Kachesova $^{2}$ \\ ${ }^{1}$ Institute of World Economy and Business, Peoples' Friendship University of Russia (RUDN University), Moscow \\ 117198, Russia \\ ${ }^{2}$ Altai State University, Institute of Mass Communications, Philology and Political Science, Barnaul 656049, Russia \\ *Corresponding author. Email: glagoleva-av@rudn.ru
}

\begin{abstract}
In November 2019, the authors conducted a survey of Bachelor's and Master's degrees students, Ph.D. candidates, teachers and employees of RUDN University. The aim of the study was to identify the role of corporate culture in the reputation development of the university, as well as the place of academic discourse in this process. Corporate culture is a complex of traditions and values of an organization supported by an extensive communication system. Based on the results of the study, the authors assessed the impact of corporate culture on the reputation of an educational institution. Also the characteristics of academic discourse were identified and the practice of corporate communications of RUDN University was studied. At the same time, the authors made recommendations for the creation of a corporate culture for global universities.
\end{abstract}

Keywords: communications; academic discourse; corporate culture; reputation, university

\section{INTRODUCTION}

The study of corporate culture began more recently. Despite the fact that the term appeared in the 19th century, the practice of the evolvement of corporate communications has place in the 20th century. Suitably the study of corporate culture in Europe and the United States began in the second half of the twentieth century [6], [8]. The first works on this issue were published in Russia only at the turn of millennium [4], and now the development of this range of issues is being carried out in different directions. One of them is the corporate culture of a modern university, as well as the influence of traditional academic culture and discourse. In this regard, in November 2019, we conducted a survey of Bachelor's and Master's degree students, Ph.D. candidates, teachers and employees of the Peoples' Friendship University of Russia (RUDN University). One of the tasks was to identify regularly represented characteristics of academic discourse in the practice of corporate communications which have developed at the university. Also we studied their role in the creation and strengthening of an university's reputation. This has made possible to develop recommendations for strengthening the reputation of an educational organization and for optimizing communication processes with the aim of promoting the university on global market of educational services.

\section{MATERIALS AND METHODS}

\subsection{Selection of respondents}

In November 2019, we made the survey of teachers, employees and students of all courses and forms of education of RUDN University in relation to the study of the corporate culture of the university in general and the academic culture in particular. 108 respondents of the first group and 176 respondents of the second group took part in the study.

They included people of three faculties (Faculty of Economics, Faculty of Russian Language and General Educational Disciplines, Faculty of Humanities and Social Sciences), four institutes (Institute of Foreign Languages, Agrarian and Technological Institute, Institute of Medicine and Law Institute), various administrative and economic services of the university.

\subsection{The structure of the questionnaire}

The respondents were asked to answer anonymously the open, closed and semi-closed questions of the survey, which make it possible to assess the corporate culture and academic discourse that has developed at RUDN University. 
In addition, the questionnaire contained traditional blocks. These are an introductory part with explanations of the goals and objectives of the research and with instruction for completing the questionnaire, a part with information on the formal demographic characteristics of the respondents and as well as a part with expression of gratitude to the respondents for attention and time spent.

\section{RESULTS AND ANALYSIS}

The authors fixed the findings after processing the information obtained as the result of the questionnaire of the students, the Ph.D. candidates, the teachers and employees of RUDN University. They allow to describe the deep-laid and superficial structures of the existing corporate culture, as well as to characterize the elements of academic discourse and its role in strengthening the reputation of the university.

Formalization of the received answer options gave the following figures:

\subsection{The question "Does RUDN University have a hymn?"}

This closed question supposed a choice of one of two answer options.

- 100 respondents from the teachers and employees (92.6\%) chose the "Yes" option. 176 respondents among students $(100 \%)$ also answered positively. This is $96.3 \%$ of the total number of respondents.

- 8 respondents from university staff chose "No". This is $3.7 \%$ of the total number of respondents.

It stands to mention that the hymn accompanies most of the university's events. The obtained indicators are quite understandable by the existing corporate practice.

\subsection{The question "Does RUDN University have a student code of conduct?"}

- $\quad 171$ students knows that the university has a current student code. $97.1 \%$ of the total number of respondents chose the option "Yes".

- The "No" option was chosen by 5 respondents who don't know anything about the RUDN University's student code. This is $2.9 \%$ of the total number of the respondents.

This knowledge is based on the fact that each student should read this document and also sign that he checks out the rules contained in it and is ready to follow them.

\subsection{The question "Does RUDN University have a code of ethics for an employee I teacher?"}

- The overwhelming majority of employees and teachers answered "Yes" to this closed question These are 98 people (90.7\% of respondents).

- 10 respondents among the teaching and administrative staff gave a negative answer. This is only $9.3 \%$ of the total number of the respondents.

Information about the existence of corporate procedure was presented to the internal audience of the university quite extensively. This is facilitated by the fact that the teachers sign job descriptions with paragraphs that include abidance by rules defined by the code.

\subsection{The question "What are the 3 main disadvantages of RUDN University?"}

This open question didn't restrict the respondents in the choice of characteristics, either quantitatively or meaningfully. The respondents' assessment of the chronotope and agents of academic discourse, as well as the values of academic culture, was clearly manifested in the answers.

The teachers and employees pointed out a bureaucracy and a quality of education as the key shortage of the university. 48 respondents $(44.4 \%)$ noted the bureaucracy as the main problem of the university. It contradicts the traditional values of academic culture. They mentioned that "there are too many approvals", "decisions are taken during a long time", "the administrative structures is too big", "there isn't consolidated format for reports", "there is no division of labor between structures," "the faculties do all work" etc. 14 people $(12.9 \%)$ pay attention to various aspects affecting the quality of education. Thus, 6 respondents $(5.5 \%)$ are concerned that the educational process took a back seat to the formalization and replaced by "rush toward statistics" and "toward rating position". 5 people (4.6\%) noted a lack of practice and a low quality of education, including the quality of foreign language teaching. 3 respondents $(2.7 \%)$ noted problems in the teaching staff: "no specialists", "lack of young teachers", "lack teacher from industry".

According to the student's opinions, the main disadvantages of RUDN University are related to the infrastructure of the university. $117(66.4 \%)$ students noted this problem. A separate group of answers reveals the problem with the equipment of classrooms, coworking and recreation areas. 48 respondents $(27.2 \%)$ paid attention to this.

The students made a point that small classrooms are provided for the foreign languages study. The classrooms are often hot and stuffy. They are ill-equipped: no computers, bad microphones, uncomfortable desks and chairs, etc. In addition, the students pay attention to the fact that there are few places for free time, few seats in the 
corridors, few sockets in the coworking area, etc. Finally, 22 respondents $(12.5 \%)$ mentioned the location of the university as a lack of infrastructure. They noted the fairness of the campus from metro, home, city center and, as a result, students often get stuck in traffic jams.

The top 5 weaknesses of RUDN University are presented in Tables 1 and 2. The research group identified them on the basis of ranking according to the principle of frequency and ща generalization by the principle of semantic proximity. The most periodical weaknesses of RUDN University by the opinion of the respondents are located in vertically, and the data on the number of relevant answers of respondents are located in horizontally:

Table 1. The top 5 weaknesses of RUDN University by student's opinions

\begin{tabular}{|l|l|c|}
\hline № & \multicolumn{1}{|c|}{ Weaknesses of university } & $\begin{array}{c}\text { Number of } \\
\text { answers }\end{array}$ \\
\hline 1 & $\begin{array}{l}\text { Infrastructure of the university, } \\
\text { including the classroom } \\
\text { resource }\end{array}$ & 117 responses \\
\hline 2 & $\begin{array}{l}\text { Organization of the educational } \\
\text { process, including a timetable, a } \\
\text { module system of education and } \\
\text { a grade-rating system }\end{array}$ & 81 responses \\
\hline 3 & Cost of education & 27 responses \\
\hline 4 & $\begin{array}{l}\text { Internal communication } \\
\text { difficulties }\end{array}$ & 19 responses \\
\hline 5 & Quality of education & 16 responses \\
\hline
\end{tabular}

Table 2. The top 5 weaknesses of RUDN University by teacher's and employee's opinions

\begin{tabular}{|l|l|c|}
\hline № & \multicolumn{1}{|c|}{ Weaknesses of university } & $\begin{array}{c}\text { Number of } \\
\text { answers }\end{array}$ \\
\hline 1 & Bureaucracy & 48 responses \\
\hline 2 & $\begin{array}{l}\text { Internal communication } \\
\text { difficulties }\end{array}$ & 15 responses \\
\hline 3 & Quality of education & 14 responses \\
\hline 4 & Meal arrangements & 11 responses \\
\hline 5 & $\begin{array}{l}\text { Weaknesses in the creation of } \\
\text { unified information } \\
\text { environment }\end{array}$ & 11 responses \\
\hline
\end{tabular}

\subsection{The question "What are the 3 main advantages of RUDN University?"}

This open question allowed the respondents to offer their own answer options. The obtained results are summarized in Tables 3 and 4, in which the respondents' answer options are arranged vertically, and the data on their number are arranged horizontally.

42 people among the administrative staff and teachers $(38.8 \%)$ named the multinationality and the possibility of intercultural communication as the main advantage of the
RUDN University. This certainly corresponds to the main task that set by the creators of the university. In addition, the important advantage of the organisation is a good friendly team mentioned by 24 employees and teachers (22.2\% of answers). The respondents noted both friendly relations inside the team and between staff and students. The singly mentioned advantages are "good environment", "concern for team's well-being ", "we come as at home", etc.

Table 3. The top 5 advantages of RUDN University by teacher's and employee's opinions

\begin{tabular}{|l|l|c|}
\hline № & \multicolumn{1}{|c|}{ Advantages of university } & $\begin{array}{c}\text { Number of } \\
\text { answers }\end{array}$ \\
\hline 1 & $\begin{array}{l}\text { Internationality and intercultural } \\
\text { communication }\end{array}$ & 42 responses \\
\hline 2 & $\begin{array}{l}\text { Infrastructure and beautification } \\
\text { of the university }\end{array}$ & 25 responses \\
\hline 3 & Colleagues and environment & 24 responses \\
\hline 4 & $\begin{array}{l}\text { Opportunities for all-round } \\
\text { development }\end{array}$ & 23 responses \\
\hline 5 & Quality of education & 20 responses \\
\hline
\end{tabular}

Table 4. The top 5 advantages of RUDN University by student's opinions

\begin{tabular}{|l|l|c|}
\hline № & \multicolumn{1}{|c|}{ Advantages of university } & $\begin{array}{c}\text { Number of } \\
\text { answers }\end{array}$ \\
\hline 1 & $\begin{array}{l}\text { Teachers, students and } \\
\text { employees }\end{array}$ & 80 responses \\
\hline 2 & $\begin{array}{l}\text { Internationality and intercultural } \\
\text { communication }\end{array}$ & 77 responses \\
\hline 3 & $\begin{array}{l}\text { Opportunities in the educational } \\
\text { process }\end{array}$ & 75 responses \\
\hline 4 & $\begin{array}{l}\text { Infrastructure and beautification } \\
\text { of the university }\end{array}$ & 70 responses \\
\hline 5 & Amiability and environment & 63 responses \\
\hline
\end{tabular}

The students also share these values. People are the main advantage of RUDN University in their opinion: teachers, students and employees. $80(45.2 \%)$ respondents gave this answer. 60 (34\%) students noted "teachers" as the main value of the university. Among the answer options, the students used definitions that relate not only to the quality of knowledge of the teaching staff ("good", "excellent", "qualified", "highly qualified"), but also to the personal qualities: "responsive", "understanding", "loyal" , "interesting". Also, the students noted that "teachers mainly have professional experience" and there are "invited foreign teachers".

$10(5.6 \%)$ respondents used the word "people" ("people of different nationalities", "very good people", "interesting people", "open and knowable sort of people", "association of people", "good team" etc.) and "students" ("students from different countries", "students from all over the world", "a lot of cool guys", etc.) in their answer. 


\subsection{The question "Do you recommend your relatives and friends to enter the RUDN University?"}

- $90.9 \%$ of students and $80.6 \%$ of teachers and employees answered "Yes" to this question. They expressed their readiness to make the appropriate recommendations.

- $9.1 \%$ of the respondents among the students and $19.4 \%$ of the teaching and administrative staff gave a negative answer. This is only $14.25 \%$ of the total number of the respondents.

Such a high figure of trust and emotional attractiveness indicates that the noted negative characteristics and facts are only the markers of areas which remain to upgrade or to change. They don't play a decisive factor in the formation of the overall assessment of the university and its corporate culture.

\section{DISCUSSION}

Summing up the results of the study, we can draw a number of conclusions that are interrelated and formed a single complex.

\subsection{Corporate and academic cultures are closely interwoven with a modern university, including RUDN University}

\subsubsection{Corporate culture markers}

The corporate culture is defined as "the beliefs and ideas that a company has and the way in which they affect how it does business and how its employees behave"[2], so the attributes and repeaters such as a hymn, codes, etc. are one of the indicators of its presence in the corporate communications of the organization. They contain in a concentrated form the organization's value system and are widely known to internal audiences.

These markers of corporate culture are present in RUDN University. They are being successfully introduced into the practice of corporate communications, according to the results of the study.

\subsubsection{Academic culture as part of corporate culture}

Since researchers call academic culture as the core of the corporate culture of the university [1], institutes of higher education have values that unite the entire university community. This paradigm of values was presented in The Bucharest Declaration concerning Ethical Values and Principles for Higher Education in Europe, which is the culmination of the International Conference on Ethical and Moral Dimensions in Higher Education and Science in Europe held by the UNESCO European Center for Higher Education in Bucharest on September 2-5 2004 [7].

Signs and components of academic discourse, rituals and values of academic culture, etc. are clearly manifested not only in the corporate hymn or at the events, but also at the level of positive characteristics of RUDN University, presented by the survey respondents. So, the internationalization was inherent in medieval universities [5]. The interaction of teachers and students is a key resource of emotional attraction that determines the reputation of an university. This is the natural principle of academic discourse. A friendly atmosphere allows to show creativity and freedom in new knowledge retrieval. The nonearning activity of students as a value of academic culture is reflected even in the Gaudeamus hymn, which has connected student youth through the centuries.

The bureaucracy is noted as one of the key disadvantages of the university. It can be assessed as a circumstance that frustrates the academic culture with its critical thinking, academic freedom and autonomy. Thus, the academic culture of RUDN University as part of the corporate culture maintains the university's positive reputation and provides the basic ideas for the internal audience.

\subsection{Corporate culture with values and traditions of the academic culture promotes the strengthening of an university's reputation}

An effective corporate culture has 3 levels of representation: superficial (level of artifacts), subsurface (level of proclaimed ideas) and deep-laid (level of basic ideas) [8]. In this regard, the following seems to be important:

\subsubsection{Attitude as a marker of sustainable positive reputation}

The respondents demonstrated the attitude towards RUDN University during the research which related to the values of academic culture. This is a marker of a stable positive reputation. The emotional component of reputation includes admiration, respect and trust, as well as atmosphere, etc. The survey's respondents rate it positively. Such advantages of RUDN University as people (teachers, students, administrative staff), intercultural communication, friendliness, etc. work for the reputation of the organization. Moreover, the reputation of a brand most of all depends on the emotional attitude towards it, which is influenced by the quality of services, the state of the working environment and the measure of the company's social responsibility, according to the published article of Ch. Fombrunn and B.M. Van Riel Cees "Fame and Fortune: How Successful Companies Build Winning Reputations" [3]. 


\subsubsection{Dissatisfaction with various aspects of university life creates areas of reputational risk}

The potential dissatisfaction with various aspects of university life, including the current corporate culture, creates areas of reputational risk. A high indicator of trust and emotional attractiveness of RUDN University for internal audiences shows that the revealed negative characteristics and facts constitute an evaluative periphery and are the markers of areas requiring improvement and / or changes. However, if they are ignored, it is likely that the indicators of emotional attractiveness and the level of trust will decrease, which can lead to reputational performance degradation of the university and the loss of its position in the educational services market.

\section{CONCLUSIONS}

The creation of a strong brand and an effective brand communication system, the strengthening of the reputation and corporate culture of a global university are closely related processes. The success of one of them is possible only with the development of the other. Moreover, the academic culture places in the core of corporate communications and culture of a modern university. The values and traditions were based in the higher education system many years ago. They remain relevant, although they are under test of time. Besides it is important to develop corporate communications in accordance with the requirements of the modern age while preserving their systemically important nature.

\section{ACKNOWLEDGMENT}

The research group is grateful to all students, teachers and employees who took part in the study, as well as to the administration of the Institute of World Economy and Business of Faculty of Economics of RUDN University for their support of the scientific initiative and the interest in its results.

\section{REFERENCES}

[1] A.V. Prokhorov, "Correlation between corporate and academic cultures of modern university" Tambov University Bulletin. Series: Humanities, no. 10, 2010, pp. 179-184.

[2] Cambridge Business English Dictionary, Cambridge. Cambridge University Press, 2011, p. 152.

[3] Ch. Fombrun, B.M. Van Riel Cees, "Fame and Fortune: How Successful Companies Build Winning Reputations," Press, 2003, 304 p.

[4] E.V. Yurieva, "Corporate culture, ideology and image: Theoretical and methodological aspect": dissertation of $\mathrm{PhD}$ candidate of sociological sciences: 22.00.01. Moscow, 1999, $174 \mathrm{p}$.

[5] I.V. Naletova, A.V. Prokhorov, "Academic culture as an idea of the university," Historical, philosophical, political and legal sciences, cultural studies and art history. Questions of theory and practice. No. 12-1 (38), 2013, pp. 137-141.

[6] T. Deal, A. Kennedy, "Corporate Cultures: The Rites and Rituals of Corporate Life," Addison: Wesley. Reading Mass. 1982, 232 p.

[7] The Bucharest Declaration concerning Ethical Values and Principles for Higher Education in Europe / Higher education in Europe, XXIX(29), No 4, December 2004, p. 503-507. DOI: https://doi.org/10.1080/03797720500083922

[8] E. Schein, "Organizational Culture and Leadership" Jossey-Bass. 1985, 458 p. 